\title{
Sustainable reuse of Modern Movement heritage buildings: problems and solutions in Scotland and Italy
}

\author{
A. Guida ${ }^{1}$, A. Pagliuca ${ }^{1} \&$ B. Dimitrijevic ${ }^{2}$ \\ ${ }^{I}$ Department of European and Mediterranean Cultures: Architecture, \\ Environment, Cultural Heritage (DiCEM), University of Basilicata, Italy \\ ${ }^{2}$ Department of Architecture, University of Strathclyde, UK
}

\begin{abstract}
Many buildings which were built in the 20th century, and due to their exceptional architectural value included in the lists of built heritage, are sometimes standing vacant for different reasons. This paper investigates the problems that need to be resolved to enable a sustainable reuse of various types of modern heritage buildings. The investigation is undertaken through case studies of some modern heritage buildings in Scotland and Italy in order to identify common problems and regional differences in enabling the reuse of those buildings. In addition, some examples of the reuse of modern built heritage are presented to highlight what has contributed to the reuse, and whether and how that meets the current environmental requirements, and the local social and economic needs.

The research indicates how public and private organisations have contributed to the successful reuse of modern built heritage and what problems they encounter in the efforts to provide new uses for the remaining vacant buildings. The investigation examines how economic, social, environmental, functional, structural and design aspects impact on defining new uses for modern heritage buildings. The analysis of the above requirements through the selected case studies leads to the recommendations on the key issues, strategies and tactics that should be considered to enable an appropriate and timely reuse of the 20th century built heritage.
\end{abstract}

Keywords: modern buildings, conservation, sustainable reuse. 


\section{Introduction}

This paper expands the collaboration on research focused on the architectural heritage of the Modern Movement in Scotland and Italy initiated through the publication on the condition assessment of two heritage buildings built of reinforced concrete: the Lion Chambers in Glasgow, United Kingdom, and the Duni Theatre in Matera, Italy [1]. While the Lion Chambers building in Glasgow is currently not in use, the Duni Theatre in Matera thrives as a cinema venue. As in the context of sustainable development, a continuous use of the built environment contributes to the achievement of social, economic and environmental goals, it is worthwhile examining what contributes to the uninterrupted use or reuse of buildings and what problems should be overcome to achieve that. In the case of the architectural heritage of the Modern Movement, the initial problem these buildings faced at the point when they were threatened with demolition was whether they were considered, evaluated and acknowledged as architectural heritage at all. The establishment of the Twentieth Century Society (initially as the Thirties Society) in 1979 in the United Kingdom [2] with the aim 'to safeguard the heritage of architecture and design in Britain from 1914 onwards' indicated increasing awareness of the need for action to preserve the best of modern architecture. However, some early examples of the transition from historicism to the Modern Movement in architecture predate this year, e.g. the Lion Chambers in Glasgow which was completed in 1907. Docomomo International, established in 1988 with the aim to alert on threats to modern architecture heritage, exchange ideas on its conservation, foster interest, and elicit responsibility towards this architectural inheritance currently has 59 chapters worldwide [3], including Docomomo UK (England and Wales), Docomomo Scotland and Docomomo Italy. Concerning the management of cultural heritage in relation to the goals of sustainable development, one of the key policy instruments is the UNESCO Recommendation on the Historic Urban Landscape (HUL), adopted by all UNESCO member states in 2011 and applied on a voluntary basis [4]. The HUL document does not aim to replace existing conservation approaches, but to serve as 'an additional tool to integrate policies and practices of conservation of the built environment into the wider goals of urban development in respect of the inherited values and traditions of different cultural contexts'. One of the HUL recommendations is 'to reach consensus using participatory planning and stakeholder consultations on what values to protect for transmission to future generations and to determine the attributes that carry these values'. The general public has been engaging in rescuing obsolescent heritage buildings across the United Kingdom through Building Preservation Trusts (BPTs). A survey of BPTs in Scotland [5] revealed that 90 trusts have been established since 1985 and that at least 49 of these are believed to still be active, involving at least 500 volunteers. The HUL recommendation on stakeholder consultation enables organisations such as Docomomo and BPTs to participate in consultations on the evaluation of architectural heritage of the Modern Movement. The application of the HUL approach has been tested in several cities across the world [6], including Edinburgh in Scotland [7] and 
Naples in Italy [8]. Along with the UNESCO's international guidance on comprehensive and inclusive management of built heritage, national policies on the management of built heritage in relation to sustainable development are developed to take into account the local environmental, social and economic context. Conservation of architectural heritage normally implies preservation of original buildings in their entirety. However, for health and safety reasons, and for the comfort of the occupants, discrete changes which improve building services infrastructure have often taken place even in buildings under the highest level of preservation. Potential further changes in building services in heritage buildings are envisaged to reduce and/or eliminate carbon emissions related to the energy sources powering building services. Historic Scotland's environment policy provides a flexible framework for improvement interventions on historic buildings by indicating that 'the protection of the historic environment is not about preventing change' with a caveat that change 'should be managed intelligently and with understanding, to achieve the best outcome for the historic environment and for the people of Scotland' [9]. The first guide on improving energy efficiency in traditional buildings in Scotland was published in 2009 [10], followed by the guide on the use of micro-renewables in heritage buildings [11]. Historic Scotland is involved in the development of a methodology for assessing the impacts of energy-related retrofit measures on heritage significance through the EU funded EFFESUS project [12]. Besides the energy-related retrofit measures, the reduction of other potential negative impacts of conservation and refurbishment interventions on heritage buildings and the environment requires a detailed knowledge of the original building materials, construction techniques, environmental services, climatic and other conditions which have impact on buildings as well as knowledge of new sustainable materials and low carbon technologies to make informed decisions on the sustainable refurbishment of these buildings. The overall condition of built heritage in relation to the expectations regarding comfort and contemporary lifestyles is generally the reason for major retrofitting. When energy saving is also a goal of such renovations, the potential for reduction of energy use could be largely exploited. Many exemplary renovation projects have been carried out, but the experience gained has not been systematically analysed and the relevant know-how gets lost in a case-by-case process. In Italy, refurbishment represents approximately $60 \%$ of all building construction sector works and, according to forecasts, could reach $80 \%$ in 2020 , which could lead to the reduction of energy consumption, and an increase in jobs and economic growth. The above brief overview of the growing interest in architectural heritage of the Modern Movement, the international guidance on inclusive management of built heritage and the national policies that stimulate sustainable retrofit of heritage buildings indicate a supportive context for preservation and sustainable reuse of the architectural heritage of the Modern Movement. Therefore, this paper aims to explore what is preventing a timely reuse of some of these buildings and what has contributed to the successful reuse of others in Scotland and Italy through selected case studies. 


\section{Pathways to the preservation of two examples of 20th century architecture in Scotland}

Although more than half a century passed between the completion of the Lion Chambers (1907) in Glasgow and St. Peter's College (1966) in Cardross, and although the former marks one of the first steps towards modern architecture while the latter is acknowledged as one of the best modernist buildings in Scotland, a clear link between the architects who designed them can be traced through two architectural practices in Glasgow: Salmon, Son \& Gillespie (19031913) [13] and Gillespie, Kidd and Coia (1927-1987) [14]. The Lion Chambers (Figures 1 and 2) was designed by James Salmon Jr (1873-1924) and John Gaff Gillespie (1870-1926) in 1904-1905 [15] after the practice James Salmon \& Son changed its name to Salmon, Son \& Gillespie in 1903. In letters to his brother, Salmon Jr wrote how the practice operated - each partner retained responsibility for certain work or clients [16]. The Lion Chambers client was William George Black (1857-1932), a prominent lawyer and a member of the Glasgow Art Club [17]. The upper six floors of the Lion Chambers were designed for lawyers' offices. Archibald Ferguson, one of the lawyers who had an office in the Lion Chambers, commissioned Salmon Jr to design the Nether Knockbuckle house in Kilmacolm whose architectural expression had been simplified more than in any previous house design, demonstrating another step in the direction of the Modern Movement [18]. This client's invitation to James Salmon Jr could indicate that he was perceived as the lead designer of the Lion Chambers who would be able to design a house for a client inclined to minimalist modern design.

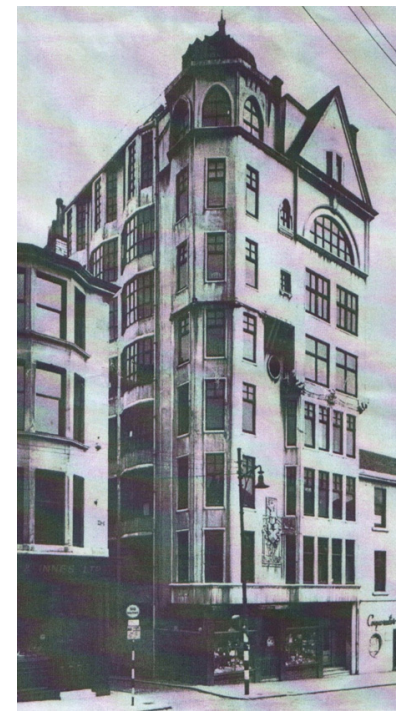

Figure 1: The Lion Chambers in early 20th century.

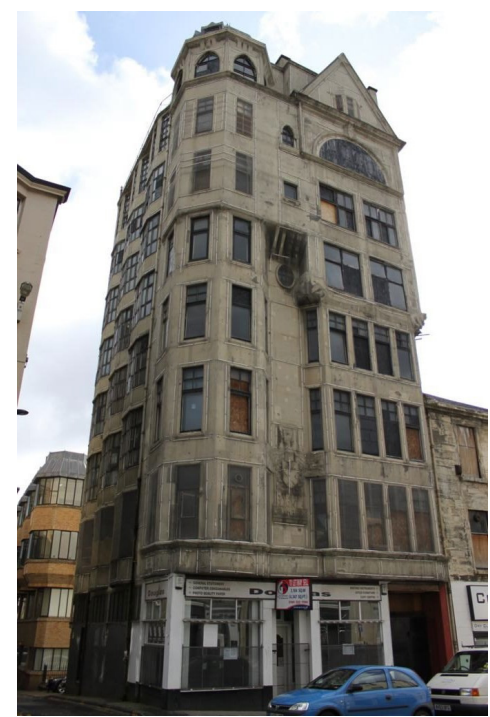

Figure 2: The Lion Chambers in 2015. 
The innovative reinforced concrete structure of the Lion Chambers was presented in detail in an article published in January 1907, showing the robustness of the Hennebique system designed by L. G. Mouchel of Yorkshire Hennebique Contracting Co. Ltd [19]. However, the presented construction details also show several weak points: no thermal insulation of the external walls and roof surfaces, and no external insulation of the basement walls against water penetration. Thus, the cold external walls, roof and foundation slab of the Lion Chambers cause condensation on internal surfaces, and water penetrates the basement. By the late 1980s the building was in need of significant repair. In 1991, a report on the condition of the Lion Chambers included information that during the investigation temporary propping of the basement and ground floor had been installed because of the damage to the concrete structure and its reinforcement from water and that the defects in the external walls had been aggravated by condensation [20]. In March 1995, as no works were undertaken following the above report, Glasgow City Council asked the owners to reinstate the structural integrity of the building [21]. As the seven co-owners were not able to finance the works, they asked for permission to demolish the building which was refused. The upper floors of the building were evacuated in 1995, with only the ground floor and basement remaining in use until 2009. Further surveys of the building condition were undertaken in 1998 and 2000. In February 2001, a feasibility study for the repair and conservation of the Lion Chambers, commissioned by Historic Scotland, concluded that additional propping of the structure was required in three other areas as the corrosion of the reinforcement had been internally exacerbated by the lack of use of the building. The report also discussed the reinforcements required for the potential future use of the building and the thermal insulation that would be needed to satisfy requirements for fuel conservation, indicating that it was theoretically possible to insulate the walls leaving a vented void (to eliminate moisture from external walls) around the internal face of the external walls. In 2015, the Lion Chambers still stands vacant and there are no immediate plans for its repair and conservation as potential sources for financing the works have not yet been identified.

St. Peter's College (Figure 3) in Cardross was designed by Gillespie, Kidd and Coia architects in 1966. By that time, only the architect Giacomo Antonio ("Jack") Coia (1898-1981) was still alive as John Gaff Gillespie died in 1927 and William Alexander Kidd (1879-1928) a year later. Without changing the practice name, Coia strengthened it by hiring Isi Metzstein (1929-2012) as an apprentice in 1945 and Andy MacMillan (1928-2014) in 1954, who became the principal designers in the practice from 1956 onwards [14]. When in 1969 Jack Coia won the RIBA Royal Gold Medal for the outstanding quality and achievement of his building work, it was noted that the building of St Peter's College significantly contributed to the nomination for the award and that Coia asked that his two partners, Metzstein and MacMillan, be associated with the award [14]. The Roman Catholic Diocese of Glasgow acquired an estate in Cardross (a large village on the north side of the Firth of Clyde, west from Glasgow) together with a mansion built in 1868 and commissioned a project for a seminary for training priests. The mansion was retained for professorial 
accommodation and became part of a new building complex containing a convent, a sanctuary and classrooms [22].

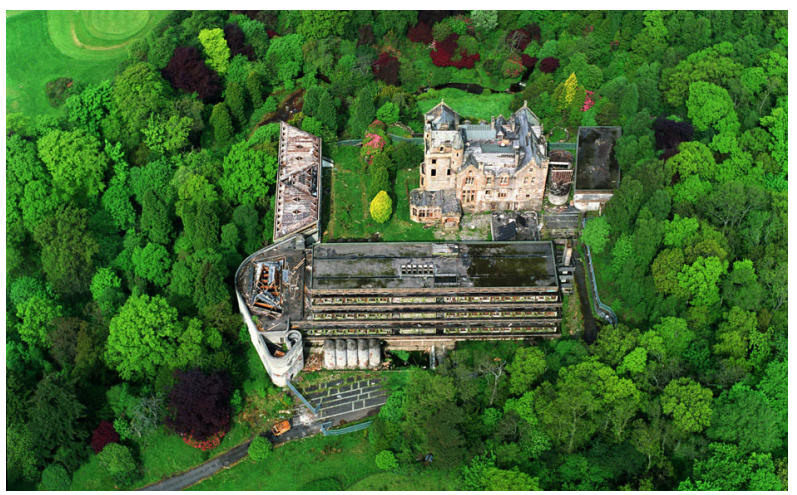

Figure 3: St. Peter's College.

The robust modernist design, inspired by the architecture of Le Corbusier, demonstrated the architects' skills in creating a dynamic composition of wellproportioned forms whose strength is emphasized by the roughness of the building materials. However, as the seminary never reached full capacity and water penetrated in some areas, it was closed in 1980. The buildings were listed by Historic Scotland as category 'A' in 1992. NVA, an environmental art group, has been developing art and community engagement projects within the $\mathrm{St}$ Peter's College estate since 2009 with financial support from various public sources [23]. In 2012, Historic Scotland provided a grant for some repair works on the buildings [24]. The NVA's plan to raise $£ 7.5$ million for the restoration of St Peter's Seminary has been successful in securing $£ 565,000$ from the Heritage Lottery Fund which should enable a second stage submission for $£ 3$ million in 2015. In January 2015, the NVA artist Angus Farquhar gave an interview to the $\mathrm{BBC}$, filmed on the site where asbestos removal work was about to begin, regarding plans for a new arts venue in St Peter's College, indicating that if funding is not raised as planned, the building might be demolished for health and safety reasons [25].

\section{The socio-cultural situation: the case of Matera (Italy)}

Throughout the first half of the twentieth century, the Basilicata - and in particular the city of Matera - were a symbol of the backwardness of the entire South of Italy: the region as well as the city essentially relied on an agricultural and rural economy, without any commercial outlets due to the absence of infrastructure connections with the rest of the country [26]. They had to wait until the 1930-1940s before reaching an important turning point in the direction of modern development of a territory marked by its age-old problems. In fact, the first attempt towards improvement was the special Zanardelli-Giolitti law (1906) 
which aimed to solve the problem of national shame of the Sassi di Matera by providing the first access to the old quarters, covering the ancient graviglioni (open sewers) and creating streets across the Sassi. With the appointment of the new provincial government by Mussolini in Matera in December 1926, a significant transformation of the urban area was undertaken, following a natural building development due to the increase of the population and economic plans introduced by the new administration [27]. The centres of the province towns were rebuilt: their historic cores rehabilitated and sometimes demolished to create new urban fabric and to build new economic services (e.g. banks and offices) [28]. In particular, in Matera the offices of the new administration were placed in old public buildings (e.g. the prefecture moved into the former Dominican convent) or in private palaces, waiting for a final accommodation. Hence the city was embellished by prestigious new buildings such as the Primary School in via Lucana - dedicated to Father Giovanni Minozzi (1927), the residential building for employees of INCIS and the building for Corporate Economics (now seat of the Chamber of Commerce), situated between via Cappelluti and via Don Minzoni. In other streets the first twentieth-century residential buildings were built. However, the construction of new administrative buildings required an urgent plan for urban transformation and modernisation of the city. Piano regolatore e di ampliamento della città, was completed by the engineer V. Corazza in 1935, remaining effective until the Piccinato's Plan, drawn up in the 1970s.

\section{The modern architecture in Matera: origin and reuse}

Along with the infrastructure improvements in the ancient Sassi (e.g. streets, ring road, public fountains and drainage) and some public housing (the buildings of via Lucana and Piccianello), the architecture of public buildings, with their unique characteristics, suspended between Rationalism and Monumentalism, were the first signs of modern architecture in Matera. This architecture created a new image of Matera and became a symbol of the new city. The representative and monumental seat of the Corporate Economic Council was designed by the architect Ernesto Bruno Lapadula and built in 1935. The high marble columns of its entrance portico and the ochre-yellow plastered pillars clearly resemble the Roman Littorio style. The building, currently in good condition, is used as the seat of the Chamber of Commerce of Matera.

However, the buildings that made the strongest mark on the city's urban fabric were built following the demolitions in the historic centre since 1936: the Bank of Naples, the Post Office Palace and the Bank of Italy. The Banco di Napoli (1936-1940) built by the engineer Francesco Silvestri, head of the Technical Office of the Bank of Naples, overlooking the central Piazza Vittorio Veneto and Via del Corso, appears as a monolithic block, severe in its shape, whose stateliness is confirmed by the giant columns within the entrance portal over two storeys high. The rest of the facade is covered in travertine, while the side facades, rising from the stone base, are articulated with large rectangular windows, framed with marble and pilasters. The top part of the building is 
composed of traditional red bricks, in typical Piacentini style. The building of the Bank of Naples, continuously in use as its headquarters, occupies a privileged location in the heart of the city and, following several maintenance interventions, it is in an excellent state of preservation. Close to the Bank of Naples, rises the Post Office (1932-1937), designed by the engineer V. Corazza. Its monumental portal, with four slightly projecting pilasters, creates a chiaroscuro effect, achieved by the use of white marble for the portal and the base, in contrast to the sandstone and red brick wall surface. The Post Office building, in good condition, is now the headquarters of Postal Police.

Not far from this building, the Bank of Italy (1946-1952) was built on the area of the demolished Convent of San Francesco. The austere neo-classical facade of the Bank of Italy rises from the white travertine base, punctuated by two rows of rectangular windows and finished by a red brick top. Until 2009, the building was the headquarters of the Bank of Italy; today, acquired by a private company, the property is subject to a reuse project for a hotel due to its suitable central location and layout (Figure 4).
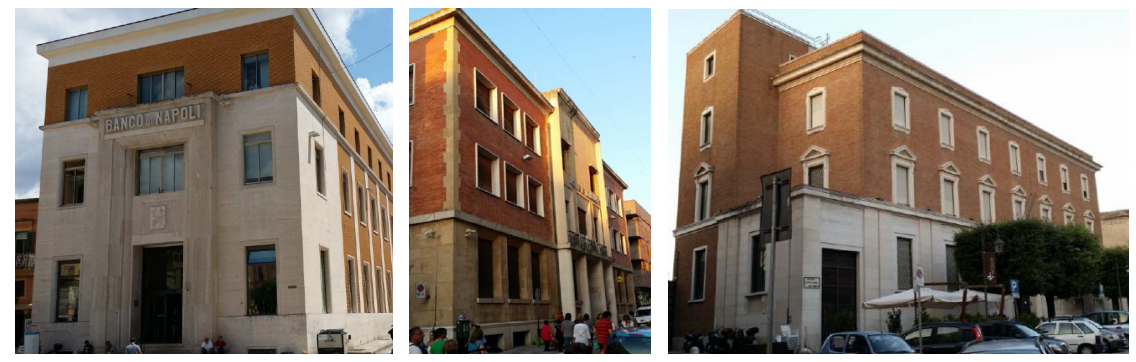

Figure 4: Banco di Napoli, Post Office and Bank of Italy.

The Holiday Camp Heliotherapeutic Vittorino da Feltre has a more rationalist architectural character. It was built with the intention of hosting the children of Matera in the summer time, to enable recreation associated with sun therapy (Figure 5).

It is an isolated building in the landscape, composed of simple volumes such as a rectangular and a half cylinder block containing the refectory surrounded by an arcade and a large canopy. Similarly to other summer resorts, there is a swimming pool with a solarium at the back for outdoor recreation. Today, the building, which has undergone significant transformations since the 1970s, is used as a high school. The House of the Mother and the Child ONMI (19461950) was designed by the architect Vincenzo Pantano in 1942. A shelter in reinforced concrete protrudes on the staircase leading to the adjacent urban park and indicates the access to the structure; its design relied on essential, minimalist, straight lines and sharp angles, with facades plastered in a light grey colour. Today, the building is abandoned and severely degraded due to vandalism, and is the subject of a redevelopment project by the municipality of Matera with the plan to turn it into a public nursery school. 

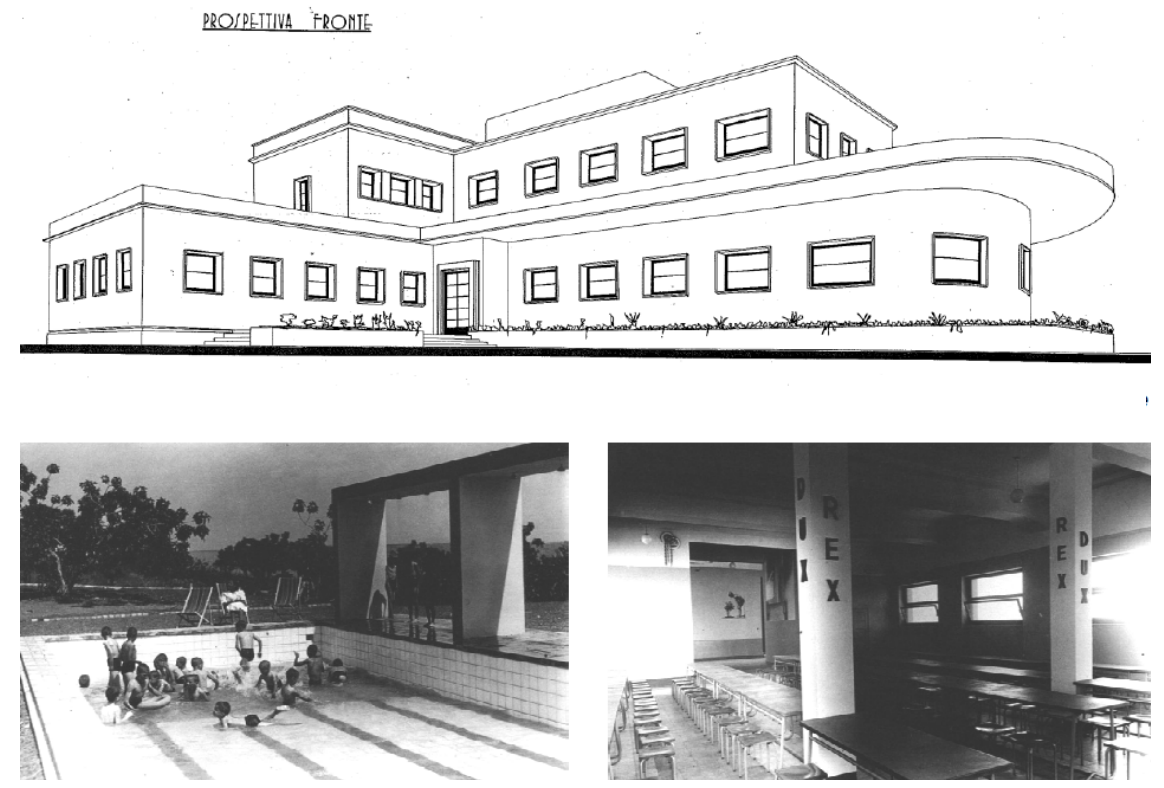

Figure 5: Holiday Camp Heliotherapeutic.

\section{Conclusions}

The case studies on the pathways to restoration and reuse of two 'A' listed buildings which marked the start and the culmination of Modern Movement in Scotland indicate the problems which caused their disuse and the efforts made to restore them and identify potential new uses. The causes of deterioration of the Lion Chambers are the lack of water-proofing in the building basement and the lack of thermal insulation on the external walls and roof surfaces. Regarding the deterioration of St Peter's College, water penetration in some parts of the building indicates poor workmanship. Degradation of both buildings was caused by technical issues: poor understanding of the physical properties of reinforced concrete structures at the time when the Lion Chambers was built and poor workmanship at the time of the construction of St Peter's College as well as lack of knowledge on the properties of asbestos regarding the impact on human health. In both cases, the lack (and the cost) of investment in maintenance exacerbated the problems until both buildings had to be vacated. The use of asbestos in St Peter's College is an additional problem regarding its restoration. The public interest in preserving both buildings is high, but the key problem on the path to their reuse is the identification of appropriate use that will attract investors. One of the barriers in attracting investors is high cost of restoration works. The laudable efforts of the NVA art group since 2009 to raise awareness of the St Peter's College condition and the need for restoration have attracted initial National Lottery funding which should cover major part of the restoration 
costs and attract other potential investors. The Lion Chambers is still waiting for a similar engagement of the enthusiasts interested in the preservation of this important example of proto-modernist architecture to initiate fund-raising activities as the available public funds are limited.

The building activity carried out by the Modern Movement in Matera has marked the history of the city, creating architecture which is now an integral part of the urban fabric because of its strategic location in lively urban areas and because the institutions for which it was designed are still active. It is an architectural heritage that deserves to be protected and preserved, maybe not as recognised for its artistic or historical value as antiquities, but because it is a testimony to the historical and technological evolution in Italy in the modern era; an era which was historically, politically, culturally and architecturally revolutionary and which represents the most important moment of transition for contemporary architecture.

\section{References}

[1] Dimitrijevic B, Guida A and Pagliuca A, Reinforced Concrete Condition Assessment in Heritage Buildings: Lion Chambers in Glasgow (UK) and Duni Theatre in Matera (Italy), Cooperativa Universitaria Editrice Studi, Fisciano, ISBN: 978-88-95028-80-4, 2011.

[2] The Twentieth Century Society, About the Society, http://www.c20 society.org.uk, accessed on 7 March 2015.

[3] DO.CO.MO.MO. International, Mission, http://www.docomomo.com, accessed on 7 March 2015.

[4] UNESCO, UNESCO Recommendation on the Historic Landscape: Recommendation Text, UNESCO, Paris, 2011, http://whc.unesco.org/en/ activities/638/, accessed on 7 March 2015.

[5] Ecotec, Study of Building Preservation Trusts in Scotland, 2010, http://goo.gl/1ikzgI, accessed on 7 March 2015.

[6] Pereire Roders A, Van Oers R, Wedding cultural heritage and sustainable development: three years after, Journal of Cultural Heritage and Sustainable Development, Vol 4, No 1, 2014, pp. 4-15.

[7] Bennink R H J, Bruin J AC, Veldpaus L and Pereira Roders A, Knowledge is power: policy analysis of the world heritage property of Edinburgh, SPANDREL - Journal of SPA: New Dimensions in Research of Environments for Living, Vol 4, No, 7, 2013, pp. 27-35.

[8] De Rosa F, Di Palma M, Historic urban landscape approach and port cities regeneration: Naples between identity and outlook, Sustainability, Vol 5, No 10, 2013, pp. 4268-4287.

[9] Historic Scotland, Scottish Historic Environment Policy, 2011. http://www.historic-scotland.gov.uk/shep-dec2011.pdf, accessed on 7 March 2015.

[10] Historic Scotland, Improving Energy Efficiency in Traditional Buildings, $2009 . \quad$ http://www.historic-scotland.gov.uk/informguide-energyefficiency.pdf, accessed on 7 March 2015. 
[11] Historic Scotland, Managing Change in the Historic Environment: MicroRenewables, $2010 . \quad \mathrm{http}$ ://www.historic-scotland.gov.uk/ microrenewables.pdf, accessed on 7 March 2015.

[12] Eriksson P, Hermann C, Hrabovszky-Horváth S and Rodwell D, EFFESUS Methodology for Assessing the Impacts of Energy-Related Retrofit Measures on Heritage Significance, The Historic Environment, Vol. 5 No. 2, July 2014, pp 132-149.

[13] O'Donnell R, The life and work of James Salmon Architect, 1873-1924, The Rutland Press, London, 2003.

[14] Rodger J, Towards the Macmillan and Metzstein years, in Gillespie, Kidd \& Coia Architecture 1956-1987, RIAS and The Lighthouse, Glasgow, pp. 6-25, 2007.

[15] Messrs. Salmon \& Son \& Gillespie Architects, 53 Bothwell St, Glasgow, March 1905. Proposed Building Hope Street for Wm Geo Black Esq. The Mitchell Library Archive, Glasgow.

[16] O’Donnell R, The Wee Troot: Letters to New Zealand, James Salmon, architect, Architectural Heritage, November 2008, Vol. 19, No. 1, pp. 2851.

[17] Eyre-Todd G, Who is Who in Glasgow in 1909, Glasgow and London, 1909.

[18] Walker, F. A., Six Villas by James Salmon, Architectural History, 1982, Vol. 25, pp. 114-119.

[19] Anonymous. A reinforced concrete office building, The Builders Journal and Architectural Engineer: Concrete and Steel Supplement (Monthly), 30 January 1907.

[20] Architect's Report, Historic Buildings Council for Scotland, Lion Chambers 170/172 and 168 Hope Street/86 and 88 West Regent Street, Glasgow; File No: FHL/B/SL/176, 22 August 1991.

[21] Notice Requiring Operations on a Dangerous Building, Building (Scotland) Act 1959, Section 13; Address 168/172 Hope Street/88 West Regent Street, Glasgow, 8 March 1995.

[22] Rodger J, Major works, in in Gillespie, Kidd \& Coia Architecture 19561987, RIAS and The Lighthouse, Glasgow, pp. 236-243.

[23] NVA work with St Peter's Seminary \& Kilmahew Woodlands. 30 April 2009, http://www.nva.org.uk/news/09-04-30/, accessed on 8 March 2015.

[24] Cardross Seminary, http://www.glasgowarchitecture.co.uk/cardross -seminary, accessed on 8 March 2015.

[25] St Peter's Seminary: Turning a 1960s ruin into art, http://www.bbc.co.uk/ news/entertainment-arts-30815285, accessed on 8 March 2015.

[26] Strazza M, "Agitazioni contadine e popolari nella Lucania fascista", Roma, 1965, p. 26.

[27] Morelli M, "Storia di Matera", Matera, 1928, p. 284.

[28] Vittorini R, "Dal centro alla periferia: costruzione e diffusione dei modelli architettonici del Ventennio fascista", Roma, 1995, pp. 40-41. 